\title{
Incidence rates of Parkinson's disease in Mexico: Analysis of 2014-2017 statistics
}

\author{
Mayela Rodríguez-Violante ${ }^{1 *}$, Leora Velásquez-Pérez ${ }^{2}$ and Amin Cervantes-Arriaga ${ }^{1,3}$ \\ ${ }^{1}$ Movement Disorders Clinic; ${ }^{2}$ Department of Epidemiology; ${ }^{3}$ Clinical Neurodegenerative Diseases Research Unit, National Institute of Neurology \\ and Neurosurgery. Mexico City, Mexico
}

\begin{abstract}
Objective: The objective of this study was to estimate and analyze the incidence and incidence rates of Parkinson's disease $(P D)$ in Mexico. Methods: Data on new cases of PD from January 2014 to December 2017 were extracted from the electronic Morbidity Annals and Epidemiological Bulletin published by the Secretary of Health. Crude and age-standardized incidence and incidence rate were calculated and compared with reports from other countries. Results: The overall incidence rate for the 2014-2017 period was 37.92/100,000 (incidence density of 9.48/100,000 person-years). The incidence rate in the 65+ population was $313.94 / 100,000$. The incidence rate was higher in men than in women (42.22 vs. 34.78/100,000, respectively). Conclusion: The incidence rate in Mexican population increases with age, and it is slightly more frequent in men but is lower in comparison to developed countries. Differences in incidence rates between developed and underdeveloped countries merit further studies.
\end{abstract}

Key words: Parkinson's disease. Incidence. Rate. Mexico.

\section{Tasa de incidencia de la enfermedad de Parkinson en México: Análisis de 2014-2017}

\section{Resumen}

Objetivo: Estimar y analizar las tasas de incidencia e incidencia de la enfermedad de Parkinson en México. Métodos: Se extrajeron los datos sobre nuevos casos de enfermedad de Parkinson de enero de 2014 a diciembre de 2017 de los Anales de Morbilidad y del Boletín Epidemiológico publicados por el Secretario de Salud. Se calculó la incidencia y la tasa de incidencia bruta y estandarizada por edad; y se compararon con informes de otros países. Resultados: La tasa de incidencia global para el período 2014-2017 fue de 37.92 por 100.000 (densidad de incidencia de 9.48 por 100,000 personas-año). La tasa de incidencia en la población de más de 65 años fue de 313.94 por 100,000. La tasa de incidencia fue más alta en hombres que en mujeres (42.22 vs. 34.78 por 100,000, respectivamente). Conclusión: La tasa de incidencia en la población mexicana aumenta con la edad y es ligeramente más frecuente en los hombres, pero es menor en comparación con los países desarrollados. Las diferencias en las tasas de incidencia entre los países desarrollados y subdesarrollados merecen un mayor estudio.

Palabras clave: Enfermedad de Parkinson. Incidencia. Tasa. México.

\section{Correspondence:}

*Mayela Rodríguez-Violante

Clínica de Trastornos del Movimiento

Instituto Nacional de Neurología y Neurocirugía

Insurgentes Sur, 3877

Col. La Fama

Date of reception: 09-03-2018

Date of acceptance: 06-11-2018

C.P. 14269, Mexico City, Mexico

E-mail: mrodriguez@innn.edu.mx
Available online: 18-06-2019 Rev Mex Neuroci. 2019;20(3):136-140 www.revmexneurociencia.com 1665-5044/O 2018. Academia Mexicana de Neurología A.C. Published by Permanyer México. This is an Open Access article under the terms of the CC BYNC-ND license (http://creativecommons.org/licenses/by-nc-nd/4.0/). 


\section{Introduction}

Parkinson's disease (PD) is the second most common neurodegenerative disease after Alzheimer's disease. PD is rare before age 50 but increases dramatically after age 60 . Its prevalence rises from $107 / 100,000$ in persons between 50 and 59 years old up to $1087 / 100,000$ in persons $>70$ years ${ }^{1}$. Furthermore, PD is more frequent in men than women².

Due to changing patterns of population age distributions and life expectancy, it is expected that the incidence of PD will increase exponentially in the next couple of decades. It has been projected that the number of persons with PD will double from 2005 to $2030^{3}$. Moreover, modification of other related factors such as smoking prevalence may result in up to a $10 \%$ increase is such estimates ${ }^{4}$. Currently, no proven neuroprotective or disease-modifier treatment for PD is available. Consequently, PD will still be considered a health problem affecting the quality of life of those who have the disease, as well as their relatives and carers.

Epidemiological data regarding PD in Latin America are scarce. At 1,960,189 $\mathrm{km}^{2}$ and with over 119 million people, Mexico is the third largest country and the third most populated in Latin America (14 ${ }^{\text {th }}$ and $11^{\text {th }}$ worldwide, respectively). In addition, Mexico harbors an extraordinary ethnic and genetic diversity ${ }^{5}$.

The objective of this paper is to describe the incidence of PD using data for a nation-wide electronic database.

\section{Materials and methods}

The incidence of PD in Mexico was estimated over the period from January 2014 to December 2017 using a national electronic database. Since 1994, the General Direction of Epidemiology enabled the Epidemiological Surveillance Automated System (SUAVE), an electronic system developed for collection, recording, analysis, and dissemination of data. However, it was until 2014 that PD (ICD-10 Code G20) was included in the weekly report form. Currently, all new cases of PD are reported on weekly basis categorized by state, sex, age group, and institution of the National Health System using a standardized procedure. In addition, data are regularly evaluated for compliance and consistency. Yearly data are summarized and published on the first trimester of the following year in the Morbidity Annals ${ }^{6}$. In addition, weekly data are published as an electronic Epidemiological Bulletin and made publicly available at the Secretary of Health website ${ }^{7}$. The SUAVE system covers $78.46 \%$ of the Mexican population.
Demographic groups were predefined by age as follows: 20-24, 25-44, 45-49, 50-59, 60-64, and 65+. Estimates of population were obtained from the projections of population growth 2010-2050 of the National Council for Population available to the public at their website ${ }^{8}$. There was no requirement for ethical approval for this study. A waiver of informed consent was approved by the local ethics committee due to the retrospective nature of the study and the fact that no identifying information was used.

\section{Statistical analysis}

Incidence proportion (cumulative incidence) was calculated using the number of new cases of PD during a 4-year period (2014-2017) as numerator and the population at the start of time interval as denominator. Incidence rates were calculated by dividing the number of new cases of PD by the estimated mid-year population. Incidence rates were computed per 100,000 individuals. Confidence intervals $(95 \% \mathrm{Cl})$ were calculated assuming a Poisson distribution, as the event of interest was rare. Stratified incidence rates were calculated across gender, age band, and time. Incidence density (average rate) was calculated by dividing the number of new cases of PD during the specified time interval by the summed person-years of observation (person-years at risk). The average annual percent change (AAPC) was calculated as described by Fay et $\mathrm{al}^{9}$.

\section{Results}

\section{Data quality}

The summarized reports (by gender and age group) from the Morbidity Annals 2014-2017 were reviewed. In addition, a total of 208 weekly reports from January 2014 to December 2017 were collected. Seven reports were not available online (two from 2014, four from 2015, and one from 2016); however, since each bulletin included the accumulated frequencies, the missing data could be inferred. In addition, data were completed for gender. In the case of age groups, 70 cases (16 in 2014, 23 in 2015, 13 in 2016, and 28 in 2017) were not categorized due to missing data and were excluded from age group analyses.

\section{Overall incidence}

The total number of new (incident) cases between 2014 and 2017 was 28,457 . The incidence proportion for the specified time interval was $0.04 \%$. The overall 
Table 1. Overall and annual incidence of Parkinson's disease in subgroups by gender and age

\begin{tabular}{|c|c|c|c|c|}
\hline Incidence & 2014 & 2015 & 2016 & 2017 \\
\hline $\begin{array}{l}\text { Overall } \\
\text { Incident cases } \\
\text { Incidence rate* }\end{array}$ & $\begin{array}{c}5057 \\
6.74(95 \% \text { Cl 6.57-6.93) }\end{array}$ & $\begin{array}{c}7273 \\
9.52(95 \% \text { Cl } 9.30-9.74)\end{array}$ & $\begin{array}{c}8009 \\
10.30(95 \% \text { Cl 10.07-10.53) }\end{array}$ & $\begin{array}{c}8118 \\
10.26(95 \% \text { Cl 10.04-10.49) }\end{array}$ \\
\hline $\begin{array}{l}\text { By gender } \\
\text { Male } \\
\text { Incident cases } \\
\text { Incidence rate* } \\
\text { Female } \\
\text { Incident cases } \\
\text { Incidence rate* }\end{array}$ & $\begin{array}{c}2666 \\
7.47(95 \% \text { Cl } 7.26-7.84) \\
2391 \\
6.08(95 \% \text { Cl } 5.89-6.39)\end{array}$ & $\begin{array}{c}3848 \\
10.60(95 \% \text { Cl 10.03-11.04) } \\
3425 \\
8.54(95 \% \text { Cl } 8.34-8.92)\end{array}$ & $\begin{array}{c}4168 \\
11.28(95 \% \text { Cl } 6.57-6.93) \\
3841 \\
9.41(95 \% \text { Cl 9.20-9.81) }\end{array}$ & $\begin{array}{c}4232 \\
11.27(95 \% \text { Cl } 10.92-11.60) \\
3886 \\
9.36(95 \% \text { Cl } 9.06-9.65)\end{array}$ \\
\hline $\begin{array}{l}\text { By age group } \\
20-24 \\
\text { Incident cases } \\
\text { Incidence rate* } \\
25-44\end{array}$ & $\begin{array}{c}20 \\
0.19(95 \% \mathrm{Cl} 0.11-0.29)\end{array}$ & $\begin{array}{c}30 \\
0.28(95 \% \mathrm{Cl} 0.18-0.40)\end{array}$ & $\begin{array}{c}18 \\
0.17(95 \% \text { Cl } 0.09-0.26)\end{array}$ & $\begin{array}{c}22 \\
0.22(95 \% \mathrm{Cl} 0.14-0.33)\end{array}$ \\
\hline $\begin{array}{l}\text { Incident cases } \\
\text { Incidence rate* } \\
45-49\end{array}$ & $\begin{array}{c}149 \\
0.42(95 \% \text { Cl } 0.35-0.49)\end{array}$ & $\begin{array}{c}233 \\
0.65(95 \% \text { Cl } 0.57-0.74)\end{array}$ & $\begin{array}{c}137 \\
0.38(95 \% \text { Cl } 0.31-0.45)\end{array}$ & $\begin{array}{c}151 \\
0.42(95 \% \text { Cl } 0.35-0.49)\end{array}$ \\
\hline $\begin{array}{l}\text { Incident cases } \\
\text { Incidence rate* } \\
50-59\end{array}$ & $\begin{array}{c}158 \\
2.28(95 \% \text { Cl 1.94-2.66) }\end{array}$ & $\begin{array}{c}233 \\
3.27(95 \% \text { Cl } 2.86-3.71)\end{array}$ & $\begin{array}{c}261 \\
3.57(95 \% \text { Cl 3.15-4.03) }\end{array}$ & $\begin{array}{c}293 \\
3.92(95 \% \text { Cl } 3.49-4.39)\end{array}$ \\
\hline $\begin{array}{l}\text { Incident cases } \\
\text { Incidence rate* } \\
60-64\end{array}$ & $\begin{array}{c}635 \\
6.04(95 \% \text { CI 5.58-6.53) }\end{array}$ & $\begin{array}{c}958 \\
8.83(95 \% \text { Cl 8.28-9.41) }\end{array}$ & $\begin{array}{c}1038 \\
9.27(95 \% \text { Cl 8.72-9.85) }\end{array}$ & $\begin{array}{c}1070 \\
9.26(95 \% \text { Cl 8.72-9.83) }\end{array}$ \\
\hline $\begin{array}{l}\text { Incident cases } \\
\text { Incidence rate* } \\
65+\end{array}$ & $\begin{array}{c}672 \\
18.28 \text { (95\% CI 16.92-19.71) }\end{array}$ & $\begin{array}{c}962 \\
25.12(95 \% \text { CI 23.56-26.76) }\end{array}$ & $\begin{array}{c}992 \\
24.89(95 \% \text { Cl 23.37-26.49) }\end{array}$ & $\begin{array}{c}1058 \\
25.56(95 \% \text { CI 24.04-27.12) }\end{array}$ \\
\hline $\begin{array}{l}\text { Incident cases } \\
\text { Incidence rate* }\end{array}$ & $\begin{array}{c}3407 \\
42.63(95 \% \text { Cl } 41.21-44.08)\end{array}$ & $\begin{array}{c}4834 \\
58.55(95 \% \text { CI 56.91-60.22) }\end{array}$ & $\begin{array}{c}5550 \\
65.20(95 \% \text { Cl } 64.34-67.83)\end{array}$ & $\begin{array}{c}5496 \\
62.23(95 \% \text { Cl 60.60-63.89) }\end{array}$ \\
\hline
\end{tabular}

*Per 100,000 persons. Cl: Confidence interval

incidence rate for the 2014-2017 period was $37.92 / 100,000$ with an incidence density of $9.48 / 100,000$ person-years. Table 1 summarizes the annual incidence and incidence rate by gender and age group, and table 2 includes the annual incidence by state. The AAPC drawn from the data was $26.70 \%$ for the period $2014-2017$. Nevertheless, the percentage change from 2014 to 2015 was $43.82 \%$, while the change from 2015 to 2016 and from 2016 to 2017 was $10.13 \%$ in both the cases.

\section{Incidence by gender}

A total of 14,914 men were diagnosed with PD during the 4-year period for an incidence rate of $42.22 / 100,000$. On the other hand, 13,543 women were diagnosed with PD, with an incidence rate of $34.78 / 100,000$. The maleto-female ratio was 1.10 .

\section{Incidence by age group}

As mentioned before, $70(0.25 \%)$ cases could not be classified by age group. Consequently, a total of 28,387 incident cases were included for this analysis. Stratified according to age the incidence rate increased sharply in the $>60$ groups. The incidence rate in people $\geq$ 45 years of age was $94.86 / 100,000$ (incidence density of $23.72 / 100,000$ person-years), while incidence rate in the $65+$ group was $313.94 / 100,000$ (incidence density of 78.49/100,000 person-years). Conversely, incidence rate in people $<45$ years was 1.66/100,000 (incidence density of $0.42 / 100,000$ person-years).

\section{Discussion}

Neurodegenerative diseases such as PD are expected to become more prevalent as population ages. PD prevalence has been reported to be between 217.22 and $308 / 100,000$ persons $^{10,11}$. PD incidence in Europe, Asia, and North America varies widely. The parkinsonism incidence in Northeast (PINE) Scotland (a total population of 311,357 ) study (PINE) reported an overall annual incidence of $17.9 / 100,000^{12}$, while a similar study carried out in the Northeast of England (total population of 488,576 ) reported a crude incidence of $15.9 / 100,000$ 
Table 2. Overall and annual incidence of Parkinson's disease by state and year

\begin{tabular}{|c|c|c|c|c|}
\hline \multirow[t]{2}{*}{ State } & \multicolumn{4}{|c|}{ Incidence rate per 100,000 habitants } \\
\hline & 2014 & 2015 & 2016 & 2017 \\
\hline Aguascalientes & 1.96 & 5.12 & 12.76 & 12.37 \\
\hline Baja California & 13.08 & 11.30 & 9.82 & 8.20 \\
\hline Baja California Norte & 10.03 & 11.93 & 8.53 & 55.00 \\
\hline Campeche & 0.71 & 10.56 & 11.01 & 9.12 \\
\hline Coahuila & 16.84 & 1.70 & 1.93 & 15.65 \\
\hline Colima & 26.20 & 19.18 & 25.82 & 23.82 \\
\hline Chiapas & 6.26 & 3.79 & 5.94 & 5.23 \\
\hline Chihuahua & 12.19 & 8.99 & 22.34 & 22.58 \\
\hline Mexico City & 3.40 & 9.14 & 9.38 & 8.28 \\
\hline Durango & 9.28 & 27.30 & 21.11 & 21.25 \\
\hline Guanajuato & 0.95 & 3.10 & 3.61 & 5.25 \\
\hline Guerrero & 3.11 & 8.60 & 7.38 & 7.68 \\
\hline Hidalgo & 10.90 & 7.34 & 8.02 & 8.73 \\
\hline Jalisco & 5.65 & 16.52 & 17.01 & 18.47 \\
\hline Estado de México & 5.47 & 5.13 & 5.65 & 4.49 \\
\hline Michoacan & 7.64 & 7.77 & 10.02 & 9.38 \\
\hline Morelos & 20.22 & 19.59 & 18.05 & 16.33 \\
\hline Nayarit & 15.64 & 13.57 & 14.02 & 11.47 \\
\hline Nuevo León & 1.44 & 11.51 & 8.37 & 9.39 \\
\hline Оахаса & 7.71 & 12.35 & 10.59 & 6.91 \\
\hline Puebla & 4.30 & 10.30 & 8.13 & 7.78 \\
\hline Querétaro & 0.74 & 6.71 & 5.86 & 4.96 \\
\hline Quintana Roo & 8.68 & 6.36 & 6.24 & 6.13 \\
\hline San Luis Potosí & 3.19 & 9.41 & 10.30 & 13.79 \\
\hline Sinaloa & 21.76 & 27.70 & 33.44 & 26.82 \\
\hline Sonora & 12.39 & 11.98 & 13.43 & 14.10 \\
\hline Tabasco & 6.91 & 5.91 & 6.99 & 8.23 \\
\hline Tamaulipas & 3.87 & 13.67 & 12.87 & 13.45 \\
\hline Tlaxcala & 4.05 & 8.06 & 11.76 & 8.21 \\
\hline Veracruz & 4.30 & 9.07 & 11.66 & 12.29 \\
\hline Yucatán & 11.32 & 7.37 & 7.45 & 6.33 \\
\hline Zacatecas & 2.72 & 2.17 & 4.37 & 5.71 \\
\hline
\end{tabular}

persons-years ${ }^{13}$. On the other hand, a study in France using a health-care insurance database reported an annual incidence of PD of $49 / 100,000$ person-years ${ }^{10}$.
In Mexican population, we found an incidence of PD from 2014 to 2017 of $37.92 / 100,000$ persons aged 20 or over. The incidence density of $9.48 / 100,000$ person-years is significantly lower in comparison with other reports.

Overall, the highest incidence rate has been reported in China; a recent meta-analysis found an incidence of PD from 1983 to 2009 of $362 / 100,000$ person-years ${ }^{14}$. Canada is second with an incidence density of $252 / 100,000$ persons $^{15}$. On the other hand, India has the lowest incidence density $\left(5.7 / 100,000\right.$ person-year) ${ }^{16}$. Regarding Latin America, Bauso et al. reported a crude incidence density of $31.2 / 100,000$ person-years in Argentina ${ }^{17}$.

$\mathrm{PD}$ is more common in men than in women. For instance, the PINE study found an incidence of $21.1 \mathrm{per}$ 100,000 in men and 14.7 per 100,000 in women; similar rates were also reported in the Northeast of England study (17.7 in men and 14.0 in women). The incidence rates in the Mexican population maintained the expected sex ratio with PD being slightly more common in men.

It is well known that PD rarely occurs before age 50 years and sharply increases after the age of 60 years $^{18}$; in Mexican population, incidence was higher in people over 45 years and over 65 years over the 4-year period ( 94.86 and 313.94/100,000, respectively). An annual incidence of $232 / 100,000$ persons has been reported in the 65 years or older Navajo population despite having a lower annual crude incidence of $22.5 / 100,000^{19}$.

On the other hand, the incidence rate in Mexican population $<45$ years of age was of $1.66 / 100,000$. In comparison, a study in Finland population reported an incidence of early onset PD $(<55$ years of age at the time of diagnosis) of 3.3/100,000 between 1995 and 2006. Interestingly, the incidence increased from 2.1 to $4.5 / 100,000$ during this period ${ }^{20}$. In our population, the incidence rate had a 1.5-fold increase from 2014 to 2016 but maintained stable afterward. More recently, Savica et al. analyzed trends in PD incidence rates in Minnesota from 1976 to 2005; they observed an increase in incidence from 10.1 to $18.5 / 100,000$ person-years ${ }^{21}$. Conversely, a study in English population from 1999 to 2009 found a downward trend with incidence rates declining between $1 \%$ and $6 \%$ depending on the case definition used ${ }^{22}$.

There are several hypotheses on this time-trends including a longer life expectancy, better symptom awareness by the patient leading to earlier diagnosis, and change in smoking habits increasing the risk of PD. It should be pointed that, in our results, there was an 
evident increase in the incidence rate from 2014 to 2015 followed by a pronounced decrease from 2015 to 2016 and the stabilizing. We cannot rule out a bias due to underreporting during the $1^{\text {st }}$ year of the inclusion of PD coding in the weekly report forms.

Our report has a number of limitations. First, coding errors and misdiagnosis cannot be ruled out. Most of the patients were diagnosed by a generalist possibly diminishing diagnostic accuracy. For example, the PINE study reported that $8.8 \%$ of the subjects changed diagnosis from PD to another disorder during follow-up ${ }^{12}$. Likewise, the National Epidemiological Surveillance System considers acceptable when $80 \%$ of the weeks are consistent in terms of diagnoses notified in a timely manner, so it is possible to have a variation of up to $20 \%$.

Second, age groups were used as provided in the database, thus limiting further analysis. Nevertheless, the correlation of age with PD incidence is non-linear and the groups of 50-59, 60-64, 65 and over were appropriate for the objectives of the study. Third, available data comprised only 4 years which prevent us from properly analyzing trend, although it allows to observe differences between age and sex groups. Furthermore, due to the pre-specified age groups, juvenile parkinsonism (age of onset $<21$ years) is not recorded. Finally, data collected only included incident cases, no information on pre-existing cases was available; consequently, point or period prevalence cannot be properly estimated.

To the best of our knowledge, this is the first report of PD incidence rate in Mexico as a whole. The 20142017 crude incidence rate of $37.92 / 100,000$ or $9.48 / 100,000$ person-years is lower than those reported in most developed countries, but when stratified by age, the incidence rate of $23.72 / 100,000$ person-years in people $\geq 45$ years is more in line with other reports. Differences in incidence rates between developed and under-developed countries merit further studies.

Sex ratio is also consistent with the current literature. Since nation-wide PD data collection is relatively new in Mexico, future analysis will be required to estimate trends.

\section{Acknowledgments}

The authors thank Dr. Gabriela del Carmen Nucamendi for her assistance regarding the use of Secretary of Health databases and General Direction of Epidemiology data.

\section{Conflicts of interest}

The authors declare that there are no conflicts of interest.

\section{Funding}

This research received no specific grant from any funding agency in the public, commercial, or not-forprofit sectors.

\section{References}

1. Pringsheim T, Jette N, Frolkis A, Steeves TD. The prevalence of Parkinson's disease: a systematic review and meta-analysis. Mov Disord. 2014;29:1583-90.

2. Elbaz A, Carcaillon L, Kab S, Moisan F. Epidemiology of Parkinson's disease. Rev Neurol (Paris). 2016;172:14-26.

3. Dorsey ER, Constantinescu R, Thompson JP, et al. Projected number of people with Parkinson disease in the most populous nations, 2005 through 2030. Neurology. 2007;68:384-6.

4. Rossi A, Berger K, Chen H, et al. Projection of the prevalence of Parkinson's disease in the coming decades: revisited. Mov Disord. 2018;33:156-9.

5. Moreno-Estrada A, Gignoux CR, Fernández-López JC, et al. Human genetics. The genetics of Mexico recapitulates native American substructure and affects biomedical traits. Science. 2014;344:1280-5.

6. Secretaría de Salud. Anuarios de Morbilidad. Dirección General de Epidemiología; 2018. Available from: http://www.epidemiologia.salud.gob. $\mathrm{mx} /$ anuario/html/anuarios.html. [Last accessed on 2018 Mar 08].

7. Matus CR, Herrera AR. Boletín Epidemiológico, Sistema Nacional de Vigilancia Epidemiológica Sistema Único de Información. Secretaría de Salud; 2017. Available from: https://www.gob.mx/salud/acciones-y-programas/direccion-general-de-epidemiologia-boletin-epidemiologico. [Last accessed on 2018 Mar 08].

8. CONAPO. Proyecciones de la Población 2010-2050; 2018. Available from: http://www.conapo.gob.mx/es/CONAPO/Proyecciones. [Last accessed on 2018 Mar 08].

9. Fay MP, Tiwari RC, Feuer EJ, Zou Z. Estimating average annual percent change for disease rates without assuming constant change. Biometrics. 2006;62:847-54.

10. Blin P, Dureau-Pournin C, Foubert-Samier A, et al. Parkinson's disease incidence and prevalence assessment in France using the national healthcare insurance database. Eur J Neurol. 2015;22:464-71.

11. Enders D, Balzer-Geldsetzer M, Riedel O, et al. Prevalence, duration and severity of Parkinson's disease in germany: a combined meta-analysis from literature data and outpatient samples. Eur Neurol. 2017;78:128-36.

12. Caslake R, Taylor K, Scott N, et al. Age-, gender-, and socioeconomic status-specific incidence of Parkinson's disease and parkinsonism in Northeast Scotland: the PINE study. Parkinsonism Relat Disord. 2013; 19:515-21.

13. Duncan GW, Khoo TK, Coleman SY, et al. The incidence of Parkinson's disease in the North-East of England. Age Ageing. 2014;43:257-63.

14. Ma CL, Su L, Xie JJ, et al. The prevalence and incidence of Parkinson's disease in China: a systematic review and meta-analysis. J Neural Transm (Vienna). 2014;121:123-34.

15. Allyson Jones $C$, Wayne Martin WR, Wieler M, King-Jesso $P$ Voaklander DC. Incidence and mortality of Parkinson's disease in older Canadians. Parkinsonism Relat Disord. 2012;18:327-31.

16. Gourie-Devi M. Epidemiology of neurological disorders in India: review of background, prevalence and incidence of epilepsy, stroke, Parkinson's disease and tremors. Neurol India. 2014;62:588-98.

17. Bauso DJ, Tartari JP, Stefani CV, et al. Incidence and prevalence of Parkinson's disease in Buenos Aires city, Argentina. Eur J Neurol. 2012; 19:1108-13.

18. de Lau LM, Breteler MM. Epidemiology of Parkinson's disease. Lancet Neurol. 2006:5:525-35

19. Gordon PH, Mehal JM, Holman RC, et al. Incidence and prevalence of Parkinson's disease among Navajo people living in the Navajo nation. Mov Disord. 2015;30:714-20.

20. Ylikotila P, Tiirikka T, Moilanen JS, et al. Epidemiology of early-onset Parkinson's disease in Finland. Parkinsonism Relat Disord. 2015;21938-42.

21. Savica R, Grossardt BR, Bower JH, Ahlskog JE, Rocca WA. Time trends in the incidence of Parkinson disease. JAMA Neurol. 2016;73:981-9.

22. Horsfall L, Petersen I, Walters K, Schrag A. Time trends in incidence of Parkinson's disease diagnosis in UK primary care. J Neurol. 2013;260: 1351-7. 